\title{
Sensor Elektrokimia, Solusi Efektif Deteksi Merkuri dalam Kosmetik
}

\author{
Hanifahzin Khatami, Gina Sabila, Hafiz Firnandi, Bunga Dacilia $H^{*}$, Izzatul Khoirunnisa \\ Program Studi Sarjana Farmasi, Fakultas Farmasi, Universitas Padjadjaran, Sumedang, 45363 \\ email: bungadacilia@gmail.com
}

\begin{abstract}
Abstrak :
Merkuri merupakan salah satu logam berat yang sangat berbahaya. Saat ini, sedang marak ditemukan sediaan obat ataupun kosmetik yang di dalamnya mengandung merkuri terutama kosmetik ilegal yang tidak berizin edar. Padahal, FDA (Food and Drug Administration) telah melarang penggunaan merkuri pada bahan makanan, obat, ataupun kosmetik karena efek sampingnya yang dapat membahayakan konsumen, seperti penipisan kulit, kerusakan saluran pencernaan, kerusakan saraf, dan bahkan kematian.Pengembangan dalam pendeteksian senyawa merkuri dalam sediaan kosmetik sudah banyak dilakukan. Salah satunya adalah dengan menggunakan Silver ink ScreenPrinted Electrode yang menerapkan prinsip sensor elektrokimia. Alat pendeteksi ini dianggap memiliki sensitifitas yang tinggi serta merespon dengan cepat terhadap senyawa uji, ekonomis, mudah dibuat, serta ramah lingkungan.
\end{abstract}

Keyword : sensor, elektrokimia, merkuri, kosmetik

\section{Outline}

- Pendahuluan

- Spektrofotometer serapan atom

- Potensiometer

- Elektroda selektif ion

- Sensor Elektrokimia yang Praktis untuk Deteksi Merkuri

- Silver ink Screen-Printed Electrode

- Biaya yang terjangkau, mudah dibuat, serta ramah lingkungan.

- Kesimpulan

\section{Pendahuluan}

Merkuri adalah logam berat yang banyak ditemukan dalam kosmetik seperti sabun dan krim pemutih. Adanya merkuri dapat menghambat produksi melanin sehingga memberikan hasil berupa kulit menjadi lebih cerah.

Padahal, adanya merkuri dalam kosmetik dapat mengakibatkan berbagai masalah kesehatan seperti kerusakan ginjal, alergi, dan kulit lebih mudah mengalami infeksi. Sehingga berbagai negara telah melarang penggunaan logam berat ini dalam kosmetik. Tetapi di Indonesia masih banyak kosmetik yang mengandung merkuri. Hal ini mendorong pentingnya pengujian keberadaan merkuri dalam kosmetik yang murah dan mudah dilakukan oleh masyarakat umum. 
Dari zaman dahulu, berbagai macam metode analisis sudah digunakan untuk mengukur kadar merkuri yang tercemar dalam linkungan, perairan, makanan, dan terlebih lagi dalam sediaan kosmetik. Melihat dari besarnya bahaya yang ditimbulkan akibat merkuri jika terlalu banyak terpapar oleh tubuh sehingga berbagai macam metode analisis bermunculan dari masa ke masa guna mempermudah pengukuran kadar merkuri.

\section{Spektrometer Serapan Atom}

Metode analisis yang digunakan untuk mengukur kadar merkuri yang paling sering digunakan dari masa ke masa yaitu menggunakan Spektrofotometer Serapan Atom. Spektrofotometer Serapan Atom (SSA) adalah suatu alat yang digunakan untuk penentuan unsur-unsur logam dan metaloid yang berdasarkan pada penyerapan cahaya oleh atom.

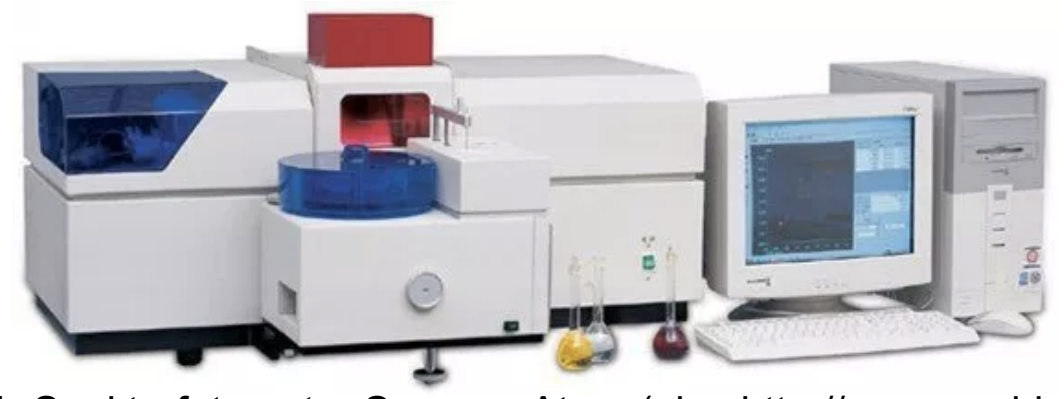

Gambar 1. Spektrofotometer Serapan Atom (pic : http://www.worldoftest.com)

\section{Potensiometer}

Saat ini sudah banyak dikembangkan metode lain untuk mengukur kadar merkuri dalam kosmetik dengan menggunakan prinsip elektrokimia. Digunakan metode potensiometri dengan membran polimer yang banyak dipakai untuk analisis ion logam berat.

Kelebihan potensiometer adalah tahapan analisis yang sederhana, cepat, pengoperasian alat mudah, dan biaya murah, dan memiliki presisi dan akurasi yang cukup baik. Dan digunakan Elektroda Selektif Ion sebagai sensor karena memiliki kepekaan terhadap aktivitas ion larutan, sehingga sensitifitas yang dihasilkan cukup tinggi.

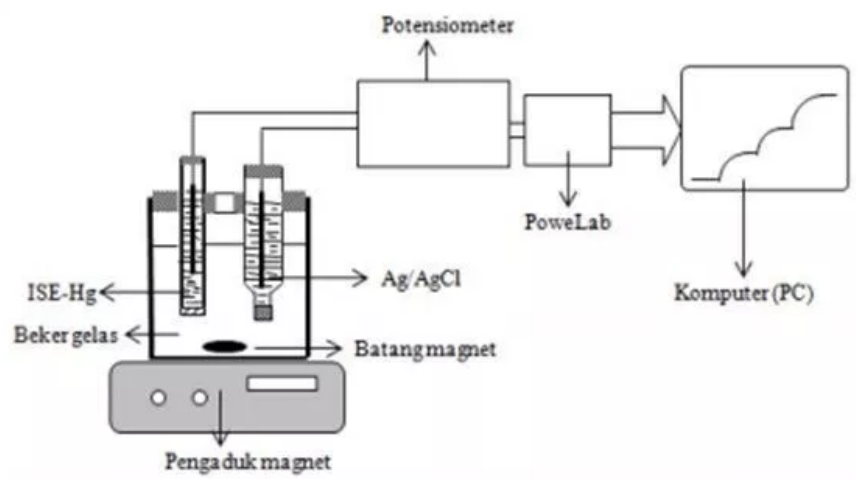

Gambar 2. Skema sistem potensiometri penentuan merkuri 


\section{Elektroda selektif ion}

Elektroda Selektif lon yang digunakan untuk mengukur kadar merkuri dapat menggunakan beberapa polimer. Pemilihan polimer yang digunakan berdasar kepada selektifitas polimer tersebut terhadap senyawa yang akan dianalisis. Polimer yang dapat digunakan untuk menganalisis merkuri diantaranya menggunakan polimer kitosan dan ionofor 7,16-Dibenzoyl-1,4,10,13-tetraoxa-7,16-diazacyclooctadecane (DTODC). Kitosan adalah biopolimer dapat digunakan karena dapat membentuk kompleks dengan ion logam merkuri melalui mekanisme pembentukan kelat atau pertukaran ion sedangkan ionofor 7,16-Dibenzoyl-1,4,10,13-tetraoxa-7,16-diazacyclooctadecane (DTODC) memberikan respon potensial yang sebanding dengan kadar merkuri. Sehingga kedua polimer tersebut dapat digunakan untuk menganalisis merkuri.

Gambar 3. Elekırouad ১еІекıII Ion Ivierkun berbasis Kitosan

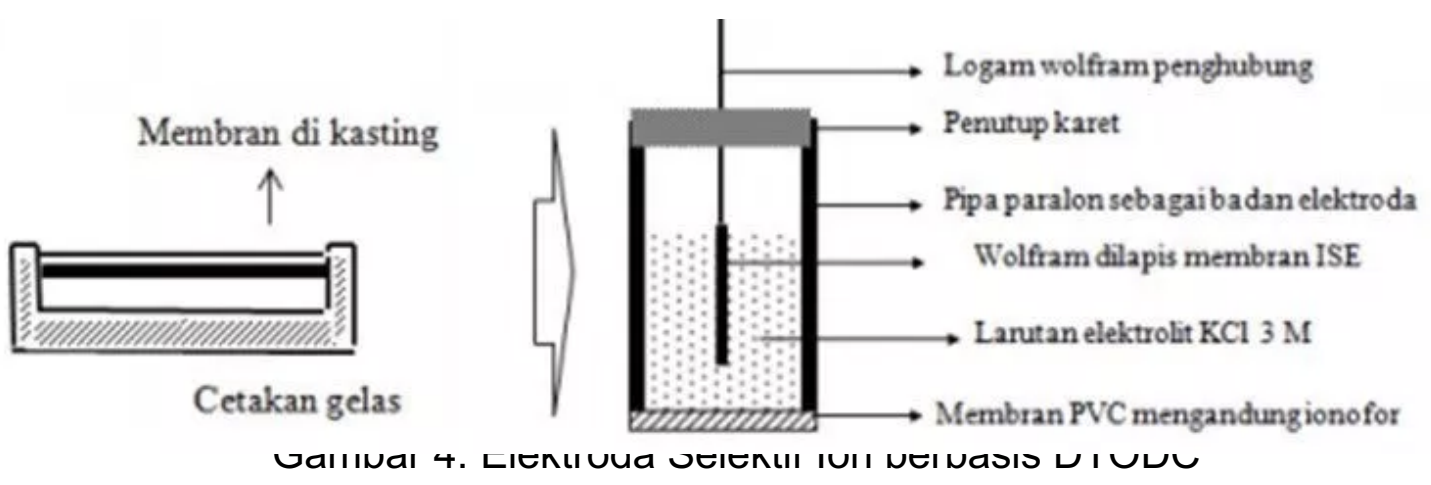

\section{Sensor Elektrokimia yang Praktis untuk Deteksi Merkuri}

Sejak tahun 1992, Food and Drug Adminstration (FDA) telah melarang adanya penggunaan senyawa merkuri serta turunannya pada makanan, obat maupun kosmetik. Tetapi, seiring berjalannya waktu masih saja banyak ditemukan adanya sejumlah senyawa merkuri yang sengaja dimasukkan kedalam formulasi sediaan kosmetik di pasaran.

Maraknya kasus penemuan senyawa merkuri pada produk makanan, minuman, obat maupun kosmetika mendorong adanya pergerakan untuk mengembangkan suatu pendeteksi senyawa merkuri. Dengan harapan dapat mengatasi permasalahan yang terjadi akibat penyalahgunaan pemakaian senyawa merkuri yang dapat membahayakan kesehatan manusia. 


\section{Silver ink Screen-Printed Electrode}

Perkembangan pendeteksi senyawa merkuri menggunakan aplikasi elektrokimia pun terlihat memiliki keuntungan tersendiri dibandingkan dengan penggunaan instrument lain seperti spektroskopi UV-Vis yang terkendala akibat seringnya muncul interferensi oleh senyawa-senyawa logam lain yang secara tidak sengaja terdapat pada sampel. Pengembangan sensor elektrokimia untuk mendeteksi senyawa merkuri memiliki target yang sama pada umumnya yaitu mengembangkan suatu sensor elektrokimia yang memiliki sensitifitas yang tinggi terhadap senyawa uji, merespon dengan cepat saat mengidentifikasi senyawa tersebut,

\section{Biaya yang terjangkau, mudah dibuat, serta ramah lingkungan.}

Terdapat beberapa sensor elektrokimia yang telah dikembangkan untuk mendeteksi senyawa merkuri, salah satu contohnya ialah sensor elektrokimia yang menggunakan penginduksi structure-switching DNA (basa timin) yang mampu mengikat merkuri secara spesifik. Selain itu, terdapat pula penggunaan Silver ink Screen-Printed Electrode dalam larutan KI.

Penelitian yang telah dilakukan oleh Chiu tahun 2008 menyatakan bahwa Silver ink Screen-Printed Electrode dalam larutan KI merupakan pengaplikasian metode elektrokimia yang memanfaatkan teknologi elektroda plat yang berbahan perak. Sensor elektrokimia ini memanfaatkan larutan KI (dalam Asam sulfat 0,05 M) sebagai agen yang mampu memisahkan merkuri dari sampel yang ada. lodine yang teroksidasi oleh perbedaan potensial elektroda akan berinteraksi dengan merkuri yang telah dicampurkan kedalam larutan $\mathrm{KI}$ dan membentuk [Hgl4]- sehingga dapat lebih mudah dideteksi oleh sensor.

\section{Kesimpulan}

Penggunaan merkuri pada kosmetik sangat berbahaya. Silver ink Screen-Printed Electrode dalam larutan KI merupakan jenis sensor elektrokimia sederhana yang dapat digunakan untuk mengetahui keberadaan merkuri dalam kosmetik. Keunggulan elektroda ini yaitu lebih praktis, sensitif, murah, dan dapat digunakan sekali pakai dengan waktu respons yang singkat. Selain itu, ukuran kecil elektroda ini memungkinkan volume sampel yang sangat kecil untuk digunakan untuk analisis.

\section{Daftar Pustaka}

[1] WHO. Mercury in Skin Lightening Product. [Diunduh 24 Juni 2018]. Tersedia dari http:/www.who.int/ipcs/assessment/public_health/mercury_flyer.pdf. (2011)

[2] Fithriani A, Zulharmita, Firda, Dinda R. Identifikasi dan Penetapan Kadar Merkuri (Hg) dalam Krim Pemutih Kosmetika Herbal menggunakan Spektrofotometri Serapan Atom (SSA). Jurnal Sains dan Teknologi Farmasi. 2013;18(1):28-34 
[3] Ayuningtyas, Imalia N, Atikah Y, Ema P, Alvan F. Development of Mercury lon Coated Wire Electrode (CWE) Base On Membranous Chitosan for Mercury lons Detection in Cosmetics. Majalah Kesehatan FKUB. 2014;1(3):161-171

[4] Jamalum P, Zainiati. Eko A S, Manihar S. Pembuatan Ion Selektif Elektroda Menggunakan Ionofor Dtodc Untuk Penentuan Merkuri (ISE-Hg). Prosiding Semirata FMIPA Universitas Lampung; Lampung, Indonesia. Indonesia: Universitas Lampung; 2010.

[5] Qualitest. Atomic Absorption Spectrometer. [Diunduh 23 Juni 2018]. Tersedia dari: http://www.worldoftest.com/atomic-absorption-spectrometer (2018).

[6] Chiu M H, Zen J M, Kumar A S, Vasu D, Shih Y. Selective cosmetic mercury analysis using a silver ink screen-printed electrode with potassium iodide solution. Electroanalysis. 2008;20(20):2265-2270.

[7] Wu D, Zhang Q, Chu X, Wang H, Shen G, Yu R. (2010). Ultrasensitive electrochemical sensor for mercury (II) based on target-induced structure-switching DNA. Biosensors and Bioelectronics. 2010;25(5):1025-1031. 